\title{
The Relationship Between Performance of the Administrative System and National Authority of Governments: An Islamic Point of View
}

M. Jafari (Mahtab Jafari, M.A.)

Political Geography, Department of Political Geography,

Faculty of Geography, University of Tehran, IR

\section{E-mail address:}

winter.556611@gmail.com

\section{Reprint address:}

Mahtab Jafari, M.A.

Political Geography

Department of Political Geography, Faculty of Geography, University of Tehran

$16^{\text {th }}$ Azar ST., Enghelab Sq. IR

Source: Clinical Social Work and Health Intervention

Volume: 9

Issue: 3

Pages: $7-18$

Cited references: 46

\section{Reviewers:}

Nasir Jalili-nasir.jalili@fmed.uniba.sk

PeriHajAli-peri93@yahoo.com

\section{Key words:}

Structure and Function of Government. National Authority. Legitimacy. Acceptance.

Efficiency of Government.

\section{Publisher:}

International Society of Applied Preventive Medicine i-gap

CSWHI 2018; 9(3): 7 - 18; DOI 10.22359/cswhi_9_3_01 @ 2018 Clinical Social Work and Health Intervention

\section{Abstract:}

Each government consists of two dimensions: 1) a structural dimension that involves policy and decision making bodies and, 2) a functional dimension that is a set of government institutions and administrations. Also, national authority in a country is an outcome of three components, including legitimacy, acceptance, and efficiency of its government. The authority of governments is not merely limited to their structural legitimacy and acceptance; but, their functional dimension and the 
performance of their administrations also play a crucial role in building and strengthening their legitimacy. Therefore, the aim of the present study is to investigate how the administrative system of a government affects its national authority, with an emphasis on the Islamic point of view. To do so, this research has been carried out within the framework of theoretical research with practical purpose. The research method of the current study was descriptive-analytical. In the present study, the relationship between two variables - namely, "administrative system" and "national authority"--has been investigated within the framework of causal research. Due to the theoretical nature of this study, the resources used mostly include documents and library resources. The results of this study indicate that there is a direct and causal relationship between the national authority of governments (effect) and the performance of their administrative system (cause). Also, this relationship reveals how the administrative system affects national authority.

\section{Introduction}

A political system is an integrated entity that is formed specifically from both structural and functional dimensions. A set of factors and institutions that constitute the structural dimension of a government include a set of institutions, such as a parliament and other organizations. It is the responsibility of these institutions to formulate policies; policies and macroeconomic strategies as well as determining the principles of its political ideology. In contrast, a group of institutions and systems that undertake the implementation of the government plans and policies in the practical dimension, constitute the functional dimension of the political system. It must be noted that from the Islamic point of view, legitimacy of a political system is provided by two sources. Firstly, it arises from Divine Satisfaction and from the conformity of its ideological framework with religious standards. Secondly, the legitimacy of a political system is provided by the will of the people and the members of society. Hence, from the Islamic point of view, the legitimacy of the government systems has a dual foundation. However, from the non-religious perspectives, it is based solely on the popular and social acceptance of the governments.
Generally, according to the basics and principles of Islam, the efficiency of governments is not confined to their structural legitimacy and acceptance. But additionally, the functional dimension and the performance of the administrations play a crucial role in building and strengthening the legitimacy of a government. The functional dimension and the performance of the administrations also assure the permanency of the legitimacy and authority of the government over time. This is a truth, not only in Islamic systems, but also in all political systems and in all eras of history. If we accept the fact that people, as the main aspect of each political system, are the key to authority and survival of governments at any given time, and their assessment of the nature of the system is mainly focused on the performance and administration of the system, and that the performance and administration of the system is the criterion of judgment about the system, the efficiency of the political system will be more salient than the legitimacy and acceptance. There is no doubt that in a case of negligence towards the functional dimension of a political system (reflected in the performance of 
its institutions and administrative bodies, and is the criterion of public satisfaction and acceptance), the structural legitimacy of the government will be negated naturally and the general authority of that political system will be abolished. Therefore, the purpose of the current study is to resolve this problem, because regardless of the ideological framework of governments, satisfaction of the people fulfilling their needs is the main component of authority and legitimacy of political systems. Therefore, according to what was explained above, in the present study, we examine how the administrative system of governments affects their national authority, with an emphasis on the Islamic point of view.

\section{Methodology}

This research is a theoretical study due to its nature; however, it can be also an applied research in terms of its purpose. This research has been carried out using a descriptive-analytical method, in order to investigate the relationship between two variables (the administrative system and the national authority) within a causal-inferential framework. Due to the theoretical nature of this study, the resources used in it mostly include documents and library resources.

\section{Findings}

Based on the basics and principles of Islam, the desirability of governments is not limited to their structural legitimacy, but is also affected by an axiom: As one of the most important and influential factors of the desirability of governments, the importance of the functional dimension and performance of the administrative bodies has a crucial role in building, reinforcing and sustaining the authority of governments over time. This axiom is true within all political systems, including both Islamic and non-Islamic political systems. In order to explain this axiom, we firstly need to explain some of the administrative and executive managers' characteristics from the perspective of Islam. Afterwards, we will describe the concepts, principles, and components of the administrative system in Islam, based on the standpoint of Imam 'Ail (AS) as reflected in Nahj al-Balagha; we will describe two categories of factors, including structural and behavioral factors:

\section{The Characteristics of Administrative Managers from the Standpoint of Islam}

\section{Knowledge and Faith}

Science and knowledge are the keys to progress and survival of governments and to the security of communities (Movahedi Nejad, 2004:100). But, obviously, science cannot be the sole protector against deviance. But, expertise must be accompanied by commitment. According to the Qur'an, the management and leadership of the earth and its inhabitants should be in the hands of competent and faithful individuals (Al-Bahi,1981:28). Virtue, meaning self-management, makes managers avoid violating the divine boundaries in favor of their personal desires.

\section{Conformity of Words and Actions}

Regarding the contradictions between words and actions, the Qur'an says: $O$ you who have believed, why do you say what you do not do? (Qur'an (61:2)). This verse revealed on the day of the Battle of Uhud, and is about Jihad and Muslims escaping the war; it refers to one of the worst disasters that may occur in an Islamic society.

\section{Consultation}

In the Qur'an (Surah: Al Imran, Verse: 159), God addresses Prophet Muhammad 
(AS) and says: consult with your men about the quality of war and act in accordance with the majority vote. Also, Imam Ali (AS) emphasizes on the principle of consultation and says: Guidance leads to increased insight. Therefore, it is necessary for managers to pay special attention to the principle of consultation, so that they can make conscious and fair decisions.

\section{Precedence of Mercy over Wrath}

Among the attributes of God is his mercy. Although Allah has determined punishment for illegitimate actions, he considers "another chance" on the basis of his mercy and forgiveness (Hamed Moqadam, 1986:124125). Regarding the verses of the Qur'an and Islamic Principles, it can be understood that reward and punishment play an effective role in the development of human personality. On-time application of these two factors can help managers to achieve constructive and productive management.

\section{Openness to the principle of negotiation}

One of the management skills is the awareness of the texts of debates and negotiations. Utilizinging these factors helps managers to be effective and productive (Fisher, 2003:13). Generally, the use of negotiation techniques is one of the most effective approaches for discovering facts and achieving better outcomes.

\section{Politics}

In Islamic management, policy is equal to the practical methods which a manager uses to deal with his opponents. It must be mentioned that the Imam Ali's goal in politics was beyond the achievement of political power, and the basis of the Imam Ali's diplomacy was a deep commitment to ethical principles and values for performing the Islamic and divine commands (Derakhshe, 1992: 206).

\section{Equality}

One of the most important requirements that each manager has to fulfil, is to recognize the facilities of organization and government institutions as the properties of the people and to avoid personal usage (Nabawi, 2011:229). Based on the ethics of all religions, violating equality is always regarded as a great oppression; those who are oppressive, will be defeated by God's will.

\section{Concepts, Principles and Components of the Administrative System in Islam, Based on the Standpoint of Imam Ali (AS) in his book, Nahj al-Balagha}

\section{Structural Factors \\ Political Factors}

Since autocratic political systems are not selected through the people's vote, they have no accountability to the people, and this is the most important factor for the development of corruption in administrative systems. Hence, in traditional approaches to the administration of government issues, the theory of separation of the administrative system from the political system in order to prevent the administrative system from being corrupted. According to this theory, managers and employees are not accountable to the people and society. But in the Islamic system, the political system is the basis of the administrative system; so correctness and corruption of the administrative system are the results of correctness and corruption in the political system. It should be said that as the public will and supervision affect the formation and sustainability of the divine political system, it also influence the decision-making process and the implementation of plans in the divine administrative system. Monitoring the performance of the 
administrative system is necessary for preserving the correctness and sustainability of the system (Sheikhi, 2011: 117).

\section{Advisory decision-making}

The logic of the Qur'an is that, even if the leader of the society has the highest position among humans (namely, the Prophet Muhammad (AS)), the Islamic community should not rely solely on him. In other words, this dependence should not be to an extent that could lead to destruction of the foundation of the society in case of Prophet Muhammad (AS) not being present (Agha Piroz et al., 2015: 116). Therefore, it is obvious that individual decisions often lead to autocracy and eventually make the whole organization inefficient. Hence, Islam has emphasized advice and consultation with others, in order to undertake the administrative actions correctly. As stated by Imam Ali (AS), anyone who consults with the wise men, will be guided in the right way (Nahj al-Balagha, Saying 173). This indicates that regarding the standpoint of Islam in general and the standpoint of Imam Ali (AS) in particular, people should use opinions of experts and wise men, but final decision must be made by a single person.

\section{Rule of Law}

The most important principle in administration is the adherence of all individuals and especially managers to the Law. Because the factor that sustains the correctness of governments and guarantees their public support is adherence to the Law. In this regard, during his deprivation of the government, Imam Ali (AS) reminded managers: There are three things that if you honor them and act based on them, you don't need anything else; and if you neglect them, nothing else will benefit you. The three things are implementing the Law equally for yourself and strangers; following God's Principles in happiness and anger; fair and equal distribution of wealth among black and white (Al-Asqalani, 1946:227).

\section{Transparency}

The concealment of issues and subjects from the sight of the people, underlies illegal and criminal actions. Generally, if all issues are clear, many problems such as: bribery; injustice; potential corruption in the Government; hidden and self-seeking relationships; hidden transactions that cannot be audited; etc. will be vanished and this increases the efficiency of the governance and management. In this regard, Imam Ali (AS) regarded the transparency of issues as the basis of government. In the beginning of his governance, Imam Ali (AS) stated: I swear to Allah that I have never concealed any truth, and I have never lied (Nahj alBalagha, Sermon 16). He also stated: It is your right and I promise that I will never hide a secret from you, unless during a war (Nahj al-Balagha, Letter 50).

\section{Accountability}

Responsibility is a prerequisite of management. This means that everyone is accountable and responsible in accordance with their role. Imam Ali has said, I recommend you to be afraid of God about what you do at your own responsibility, because you are pledged to it. Every man has a commitment to his own achievement, says God. He says, God warns you to beware of his punishment. Indeed, to him all will return. Then he says, Thus, swear to your God, I will ask all of them about what they were doing. O Servants of God, you know that God will ask you about your actions (Majlesi, 1670: 543).

\section{Organizational Supervision}

In order to prevent employees from violating the Laws and offending the rights of 
the people, as well as to preserve the integrity of the administrative system, monitoring the administrations and the employees of the departments is essential. Imam Ali (AS) wrote a letter to one of his managers and told him: I heard that you have destroyed useful lands and usurped as much as possible. Send me the details of your account immediately (Nahj al-Balagha, Letter 40).

\section{Improving the Livelihood of Employees}

Financial problems and poverty underlie many corruptions in the administrative systems. Therefore, one way to prevent administrative corruption from occurring is to improve the livelihood of employees and government managers. In the management methods provided by Imam Ali (AS), this important issue has been considered. Imam Ali (AS) told his commander (Malek Ashtar): Pay them (employees) enough, because it supports them for correcting and improving themselves. This way, they don't need to steal any amount of the public funds, and if they defy your orders or betray you, they will have no justification (Nahj alBalagha, Letter 53).

\section{Behavioral Factors}

\section{Impact of People on the Correctness of the Administrative System}

From the standpoint of Islam, without the participation of the people, the administrative system is not properly managed and its correctness cannot be guaranteed (Delshad Tehrani, 2000 b: 111). Islamic government is able to flourish only by the stability of the people and their full participation in the society. Imam Ali (AS) has tried to keep people away from dominative and submissive positions and to make them have a real presence in all areas (Delshad Tehrani, 2000 a: 111). He said: Don't speak with me the way people speak to arrogant kings. Don't walk away from me, as you walk away from angry people, and don't behave with duplicity and falsification. Don't think that if you express a truth, I'm going to get upset and don't think I'm trying to seem great. Someone who cannot tolerate hearing the truth or a complaint against injustice, would have much more difficulty for acting based on truth and justice. Therefore, don't avoid saying the truth or counseling for justice; because I don't think that I am protected from making mistakes, unless God protects me (Nahj al-Balagha, sermon 216).

\section{Institutionalizing the Culture of Criticism and Openness to Criticism}

In order to nurture the culture of criticism among the people, Imam Ali (AS) recommended his employees to get closer to the individuals who have more explicitness in speaking the truth and give constructive criticism, rather than glorifying the current actions and plans (Mohammadi Rey Shahri, 2008: 42-43). Promoting the culture of criticism against managers and organizations will lead to disclosure (and correction) of possible shortcomings and corruptions.

\section{Adherence to Justice}

According to procedural justice, when current procedures of decision-making for the allocation of resources are considered fair by individuals, they will have more motivation for improving their performance (Rezaian, 2014:49). Procedural justice can be also an important factor for getting the people to cooperate and have a profound impact on one's work attitudes in the workplace (Ibid:49).

The principle of justice was one of the most important principles of administration in the management methods offered by Imam Ali (AS). The principle of justice is the criterion of everything; and without acting in accordance with justice, the goals of the Islamic government cannot be achieved. 
It is the most important principle in social management (Delshad Tehrani, 2000 b: 246). From the standpoint of Imam Ali (AS), justice is important in managing the affairs of administration and he considered justice as the criterion of policy (Tamimi Amedi, 1999: 116). Justice is the criterion of administration means that all employees are provided with equal facilities to make progress. Also, in the formulation and implementation of the Law, justice and equality must be considered and the differences and advantages must be evaluated on the basis of qualifications and competencies (Delshad Tehrani, 2000 b: 253).

\section{Education}

In each society, education has a direct impact on beliefs, ethics, and generally, on behaviors (Mesbah, 2012: 337). In general, education plays a crucial role in informing the people of the corruption of values; malignancy of the powerful individuals; their misuse of power; as well as informing them of desirable circumstances, values and goals (Ibid:64). In other words, training the employees of the administrations has a central role in the positive development of the administrative system. Imam Ali (AS) said that the origin of any material and spiritual goodness is knowledge; and he considers ignorance as one of the key causes of corruption in any social environment. Knowledge is the basis of any goodness (Hakimi, 2001: 96), and ignorance is the root of all evils (Ibid:64).

\section{Meritocracy}

To achieve efficiency in administrations, employees have to acquire some features such as skills, knowledge, and beliefs. In other words, if incompetent people undertake the management of the administrative system, efficiency of the administrations will be reduced. From the standpoint of Islam, managers are trustees for the people. Assigning responsibility and administrative authority to competent individuals is one of the important examples of this trusteeship. As God says in Qur'an, Indeed, Allah commands you to render trusts to whom they are due and when you judge between people to judge with justice (Qur'an, 4:58). Furthermore, one of the most important principles of administrative management from the standpoint of Imam Ali (AS) was to consider competence in the process of assigning a responsibility to an individual. Imam Ali (AS) stated that assigning responsibilities to incompetent individuals leads to failure and disaster. Imam Ali (AS) addresses the judge appointed by himself and says: Government is a trust, and anyone who betrays in this trusteeship will be damned by God until the doomsday, and Muhammad (AS) hates anyone who employs a traitor in this world and in the world hereafter (Mahmoodi, 1997: 36).

\section{Punishment and Reward}

The evaluation of employee performance, rewarding competent employees and punishing offenders, collectively cause the growth and advancement of committed individuals and correction of the offenders. In a recommendation, Imam Ali (AS) told one of his commanders: Recognize their efforts through an accurate assessment and never reward someone because of someone else's efforts. Don't underrate the value of their services. The honor and dignity of individuals should not lead to overrating their works, and anonymity of some individuals should not cause you to misprize their great work (Nahj al-Balagha, letter 53).

Generally, other behavioral factors that promote correctness and improve performance of the administrative system are as follows:

- Respecting the clients: Showing respectful and pleasant behavior toward clients; 
- Face-to-face communication with people: Administrative managers in an Islamic system are obligated to investigate people's problems directly and closely. In this regard, Imam Ali (AS) says: $A u$ thorities hiding from the people are the origins of lack of awareness among the authorities (Nahj al-Balagha, letter 53);

- Public Monitoring: From the standpoint of Islam and Nahj al-Balagha, the most effective form of monitoring the performance of administrations is the robust supervision carried out by social masses who believe in Islam and the Islamic government. Hence, social differences, social classes, the type of ideological attitudes, and other factors should not prevent people from monitoring the performance of administrations and authorities;

- Judicial factors: fair judgment prevent employees from carrying out violations. In this relation, the religion of Islam has emphasized the provision of operators' rights in the judiciary system and monitoring their performance in order to preserve the correctness of the judiciary and administrative systems.

From the standpoint of Nahj al-Balagha, the government is a sociopolitical system which is assigned to the ruler or the
Governing Council by God and the people, so that social order and improvement will be realized towards material and spiritual well-being of the individual and the society (Navaei and SeyedMoosavi, 2011: 76). Imam Ali (AS) has told the rulers: Don't say that I am a king and you must obey me as this leads to a retrogression and destruction of the government. Based on the principle that proper and correct management leads to the evolution of individuals, society and government in addition to establishing a political system, Islam has defined the characteristics of administrative managers and the components governing the administrative system. In accordance with what was presented in this section of the study, these characteristics and components are as follows:

Characteristics of the Administrative Managers: A principled and ethical diplomacy; commitment and expertise; advisory decision-making; appropriate encouragement and punishment in accordance with the principles of Islam; with respect to human dignity; dignity as well as the propagation and promotion of justice.

We describe the Components Governing the administrative system in the following conceptual model: 


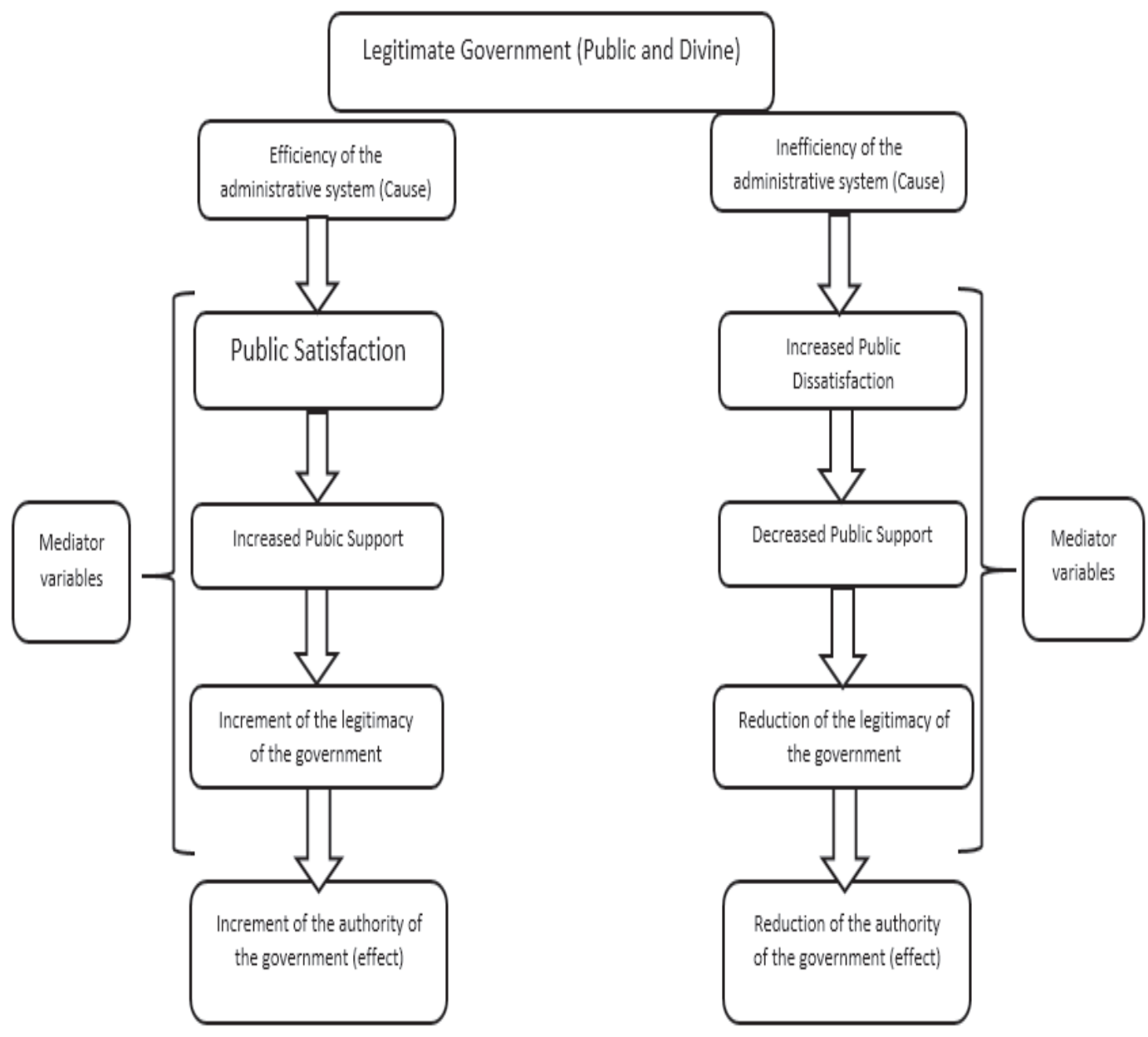

Figure 1: Conceptual model of the relationship between performance of the administrative systems in governments and national authority of the governments. (Figure 1: Author)

Components governing the administrative system: Rule of Law; the correctness and corruption in the government affecting the correctness and corruption of the administrative system; transparency; accountability; organizational supervision; improving the income of employees; the role of people in the correctness of administrative system; institutionalization of criticism and openness to criticism; meritocracy.

Therefore, considering the Islamic Principles required for the realization of an efficient political system that causes the development and improvement of the individual and society, we can understand the role of functional dimension and the performance of the administrative system in realizing, strengthening and sustaining the desirability of governments over time. Also, we believe that there is a direct and causal relationship between the administrative system (as the Cause and the Independent Variable) and the national authority of governments (as the Effect and the Dependent Variable); so that increasing the quality of performance of the administrative system leads to increased national authority of governments and, decreasing quality of the performance of the administrative system leads to decreased national authority of governments. 


\section{Conclusion}

Based on the results of the current study, we found that one of the factors for building legitimacy is the positive performance and efficiency of governments. But it must be explained that according to Islamic Teachings and Principles, legitimacy and desirability of governments are not confined to the structural legitimacy of the governments. Therefore, since the governments implement their programs and actions through their functional dimension and administrative bodies, it can be stated that the legitimacy of a government depends on both structural and functional dimensions of the government. We discovered a direct causal relationship between the two variables, including the performance of the administrative system (cause) and the national authority of governments (effect). We used the diagram above to describe how the administrative system influences the national authority of governments (Fig. 1).

It must be mentioned that in a significant number of Islamic countries, despite the existence of Islamic Principles provided for monitoring the performance of administrative systems, there are deficiencies such as the lack of transparency; accountability; reward and punishment system; meritocracy; as well as the weakness of the regulatory structures; the unfair distribution of wealth; etc. In regard to the understanding the cause of these problems in the administrative system of all countries, including both Islamic and non-Islamic, we can mention the basis of the legitimacy of governments. JeanJacques Rousseau believes that if a government and authority is delegated to an individual by the public will, it is legitimate; however, other routes for transmitting the political power are not legitimate. But from the standpoint of Nahj al-Balagha, people cannot be the sole origin of legitimacy. Because a society may suffer from intellectual, ethical and practical deviations; the people's ideas may not be rational, logical, and divine; corruption may be embodied in the intellectual bases of the community. Indeed, such an issue is quite evident in many of past and current societies. Obviously, these problems will lead to a reduction in the efficiency, acceptance, legitimacy, and finally the national authority of governments.

\section{References}

1. AGHA PIROZ A, KHEDMATI A T, SHAFEIE A, BEHESHTI N, SEYED M (2015) Management in Islam. Publication: Research Institute of Hawzah and University.

2. ALAGAPPA M (1995) Political Legitimacy in Southeast, Asia, Stanford, Stanford University Press.

3. ALAM A (1999) Foundations of Political Science, Tehran: Nay Publishing.

4. AL-ASQALANI I HAJA, AHMAD I A (1946) Al-Tahzib, Publication: Bairut, Dar Sader, Publishing Volume No. 6.

5. AL-BAHI M (1981) Islam and administration of the Government. Cairo. School of Wahbe, Second Edition.

6. BEATHAM D (2004) Legalization of Power, translated by Mohammad Abedi Ardakani, Yazd: Yazd University Press.

7. DAL R (1985) Analysis of Political Science, Translation: Hossein Mozafarian, Tehran: Moteargem Publishing .

8. DELSHAD T M (2000 A) The rule of wisdom: government in Nahj al-Balaghah, Tehran: Darya publication.

9. DELSHAD T M (2000 B) Government of the Sun: Imam Ali's Political Ideology and Administration methods. Tehran. Darya Publication.

10. DERAKHSHE J (1992) Political obstacles of Imam Ali (AS) to the opposition, publishing center of Islamic propaganda organization, first edition.

11. DIKSHIT R D (1995) Political Geography: 2nd ed, New Delhi: Tata McGraw-Hill PubCo. 
12. DOSE R, LIPSET S M (1994) Political Sociology, Translation: Mohammad Hossein Farjad, Tehran: Toos Publishing.

13. FISHER R (2003) Principles and techniques of negotiation, translation: Masoud Heydari, Tehran: Industrial Management Organization, Sixth Edition.

14. HAFEZ N, MOHAMMAD R, MORAD KI RAD. (2014) Philosophy of Political Geography, Tehran: Strategic Studies Institute.

15. HAKIMI M R, HAKIMI A, HAKIMI M (2001) Al-Hayat, Translation: Ahmad Aram, Dalille Ma Publishing.

16. HAMED M A (1986) Social traditions in the Holy Qur'an, Mashhad: Islamic Research Foundation.

17. HAMISI M, ALI K A (2011) Investigating the role of political authority in the development of national authority, Strategic Defense Studies Quarterly, No. 43.

18. JASPERS K (1984) Confucius, Translated by: Ahmad Samii, Kharazmi Publishing.

19. LIPSET S M (2004) Encyclopedia of Democracy, Ministry of Foreign Affairs.

20. MAHMOODI M B (1997) Nahj al Sa'adah fei mostadrak Nahj al-Balagha. Translated by Aziz Al-Talib. Tehran: Printing and Publishing Organization of Ministry of Culture and Islamic Guidance. Volume No. 5.

21. MAJLESI M B (1670) Bahar al-Anavr, Publication: dar al-kotob Islamiah, Reprinted in Tehran, Volume No. 3.

22. MARCUSE H (2007) About authority, translation: Mojtaba Golmohammadi and Ali Abbas Beigi, Tehran: Gam Noo Publishing.

23. MESBAH M T (2012) Society and History from the Perspective of the Quran, International Publishing Company..

24. MIR M, SEYED M, AKBAR H (2011) Iranian Administrative System: An Analysis of Problems and Challenges, The Perspective of Public Administration, No. 8, pp. 9-22.

25. MOHAMMADI R, SHAHRI M (2008) ALawi Reform, Qom, Cultural and Informational Institute of Tabian
26. MOTAGHI I, FARHAD K (2014) Elements of Legitimation in Political Systems, Political Quarterly, No. 2, pp. 335-350.

27. MOUSA Z R (2005) Administrative Law: General and Iran, Tehran: Mizan Publishing, Seventh Edition.

28. NABAWI M H (2011) Islamic Management, Qom: (Center for Publishing Islamic Propaganda Office in Qom Seminary), Sixteenth Edition

29. NAVAEI A A, SEYED H M (2011) The structure of government in Nahj alBalaghah, Quarterly of Interpretative Studies, No. 6, pp. 171-194.

30. POLITICAL SCIENCE CULTURE (2002) Oxford, translation: Hamid Ahmadi, Tehran.

31. POURAHMAD A A (2011) The Realm and philosophy of Geography, Tehran: University of Tehran press.

32. QALAMDARAN H A (1979) Government in Islam, Tehran, the Esmailian Press Institute.

33. QALIBAF M B (2007) Local government or spatial distribution of political power in Iran, Amir Kabir Publishing.

34. REZAEIAN A (2014) Expecting Justice and Justice in the Organization (Advanced Organizational Behavior Management), Publishing: Organization for the Study and Compilation of Humanities Books of Universities (samt).

35. REZAIYAN A (1993) Principles of Management, Tehran: Samt Publishing, Fourth Edition.

36. REZAIYAN A (2000) Principles of Organization and Management, Tehran: Samt Publishing.

37. ROTHSHILD J (1997) Observation on Political Legitimacy in Contemporary Europe Political Science Quarterly.

38. ROUSSEAU J-J (1989) Social Contract Theory, Translated by: Gholam Hossein Zirakzadeh, Tehran: Adib Publishing, Seventh Edition.

39. SAADAT M (2016) Explaining the Foundations of Legitimacy and Its Foundations in 
the Constitution of Iran, Quarterly Journal of Lawyers, No. 8.

40. SABINE G (1983) History of Political Ideas, Translation: Baha'addin Pazargad, Tehran, Amir Kabir Publishing, Second Edition.

41. SAINT R (1999) Authority, Translation: Bagher Parham, Tehran: Publishing Research Institute of Shirazeh, First edition.

42. SHEIKHI M H (2011) Effective factors on the health of administrative systems and the development of moral values in it, Islam and management research Quarterly, No. 2, pp. 99-126.
43. SHIRVANI A (2006) Persian Translation of Nahj al-Balagha, Tehran: Dar al-elm Publication. 5th Edition.

44. TAMIMI A, ABDUL W IBN M (1987) Qorarol Hekam and Dorarol Kalem. Translated by Mirza Hasan Khoshnevis. Qom, Publication of Islamic Propagation Office, Volume No. 1.

45. THE HOLY QURAN.

46. YOUSEFI A (2001) The Results of Measuring the Political Legitimacy of the Government in Three Cities in Tehran, Mashhad and Yazd, $\mathrm{PhD}$ Thesis, Tarbiat Modares University. 